\title{
Deformations of the Cervical and Cranial Thoracic Vertebrae in a Bedridden Asian Elephant
}

\author{
Megu GUNJI ${ }^{1,2) *}$, Akira TAKAI ${ }^{3)}$, Hideki ENDO ${ }^{1)}$ \\ 1) The University Museum, The University of Tokyo, 7-3-1, Hongo, Bunkyo-ku, Tokyo 113-0033, Japan \\ 2) Department of Global Agricultural Sciences, Graduate School of Agricultural and Life Sciences, The University of Tokyo, \\ 1-1-1, Yayoi, Bunkyo-ku, Tokyo 113-8657, Japan \\ 3) Kobe Oji Zoo, 3-1, Oji-cho, Nada-ku, Kobe-shi, Hyogo 657-0838, Japan
}

[Received 21 March 2014; accepted 24 July 2014]

\begin{abstract}
The present study reports an abnormality of the neck in a bedridden Asian elephant. When 1 year old, the elephant lost the ability to stand and grew up under the bedridden condition for 3.5 years. Our observations from CT scan revealed that the articular facets of the cervical and first 3 thoracic vertebrae possessed intricately rough surfaces and that the anterior articular processes of C4, C5 and C6 intruded to the adjacent processes. The articular processes were partly fused to the contiguous processes in the C5/C6 and T1/T2 zygapophyseal joints and the processes of C6 were completely coalesced with those of $\mathrm{C} 7$. The neck of the bedridden elephant was dorsally bent at 30.4 degrees more than that of a hyperostotic elephant. Under the bedridden condition, the nuchal ligament is contracted without the gravitational load of the head weight. This induces the dorsiflexion of the neck, and then generates a compressive force between adjacent vertebrae. The compressive force might cause the inflammation and bony destruction between the articular processes, and prompt the abnormal ossifications in the articulations through the repairing process. The abnormalities of the articular processes were identified in the attachment site of the nuchal ligament, and the vertebral fusions were distributed intensively on where the compressive force should be converged. This study concludes that a long-term lying posture under the bedridden condition might cause the over-dorsalization of the neck and the deformations of the articular processes in large mammals.
\end{abstract}

Key words: Asian elephant, bedridden, lying posture, neck, nuchal ligament

— Jpn.J.Zoo. Wildl. Med. 19(3) : 79-86, 2014

\section{INTRODUCTION}

A lying posture drastically changes a physical environment. The direction of the gravitational load is obviously different between the normal and bedridden conditions. The gravity produces a lateral direction force in a lying posture, although it is usually exerted to dorsoventral direction in normal upright posture in quadruped animals. Gravity is one of the environmental parameters that have remained constant during a period of life, thus the previous study argued that it must have been a major force in forming the body [1]. It indicates

\footnotetext{
* Corresponding author :

Megu GUNJI（E-mail: megu_850121a@yahoo.co.jp）
}

that the morphology of skeletal system might be affected by a long-term lying posture under the bedridden condition.

The Asian elephant (Elephas maximus) is the second largest terrestrial mammal, and the maximum record of body mass in the captive elephant is $6492 \mathrm{~kg}$ [2]. In such large mammals, it is difficult to keep upright posture by the artificial force when they lost the ability to stand due to injury or senile deterioration. Therefore, infrequently, elephants or other large mammals that lost a capacity to stand are reared under the bedridden condition in zoo. A previous study reported the deformations of the vertebral column and appendicular skeleton in a human who had been bedridden for 5 years [3]; however, there is little information about the deformations by the bedridden condition in large mammals. 




Fig.1 Lateral view of the vertebrae of the hyperostotic Asian elephant (NSMT-M-31593). Scale bar indicates $10 \mathrm{~cm}$.

The present study reveals the morphological deformations associated with a long-term lying posture under the bedridden condition in an Asian elephant. We utilized a skeletal specimen of a bedridden elephant that had lost the ability to stand over 3.5 years. First, we focus on the neck region and describe the deformations of the articular processes of the cervical and cranial thoracic vertebrae in the bedridden elephant. Second, we estimate the neck angle of the bedridden elephant, and infer the transformation of the angle by comparison with a hyperostotic elephant showing the vertebral fusions between cervical and cranial thoracic vertebrae. Finally, we discuss about the cause of the morphological deformities associated with a long-term lying posture by focusing on the musculoskeletal structure.

\section{MATERIALS AND METHODS}

We used a bedridden male Asian elephant (UMUT 12331) specimen that had been stored in The University Museum, The University of Tokyo, Tokyo, Japan. This individual had been in captivity in the Oji Zoo, Hyogo, Japan and was donated to the museum after its death. The elephant was born on 21 October 2007 and died on 7 April 2012. Lameness in the right forelimb was first confirmed on 16 September 2008, and X-ray pictures filmed on 30 November 2008 revealed bone fractures in the right forelimb and both hindlimbs. The bedridden elephant lost the ability to stand from 25 November 2008 until its death.

To compare with the neck structure of the bedridden elephant, we utilized a skeletal specimen of a 56-year-old female Asian elephant (NSMT-M-31593) stored in the National Museum of Nature and Science, Tokyo, Japan. The spine of this specimen was fused from C2 to T5 (Fig. 1). This elephant had been reared without the bedridden condition although it had suffered a hyperostosis of the vertebrae stemmed from aging. The axial skeleton is usually separated to each vertebra in the process of making the skeletal specimen, and we cannot confirm the angle of the neck from the separated vertebrae. The unified vertebrae of this hyperostotic elephant enable us to infer the neck angle from the skeletal specimen, thus we used this as an indicator of the neck angle uninfluenced by the bedridden condition.

The bedridden elephant was subjected to computerized tomographic (CT) imaging to observe the articulated axial skeleton in detail and morphologically clarify the deformations of the neck structure. We described the shape of the articular processes and facets of the cervical and thoracic vertebrae in the bedridden elephant.

To quantitatively investigate the abnormality of the angle of the neck in the bedridden elephant, we defined the inclination consisting of the cervical vertebrae as the neck angle, and calculated it in both the bedridden and hyperostotic elephants by conducting an image analysis. The unified vertebrae between the cervical and cranial thoracic vertebrae were filmed from a left lateral view in the hyperostotic elephant (Fig. 1). We obtained the corresponding image in the bedridden elephant from the CT scan data (Fig. 2). Furthermore, we converted the locations of the characteristic points of the vertebrae to the 2-dimension coordinates by using the image analysis free software ImageJ (version 1.46r; National Institutes of Health, Bethesda, USA, from http://imagej.nih.gov/ij/). We digitized

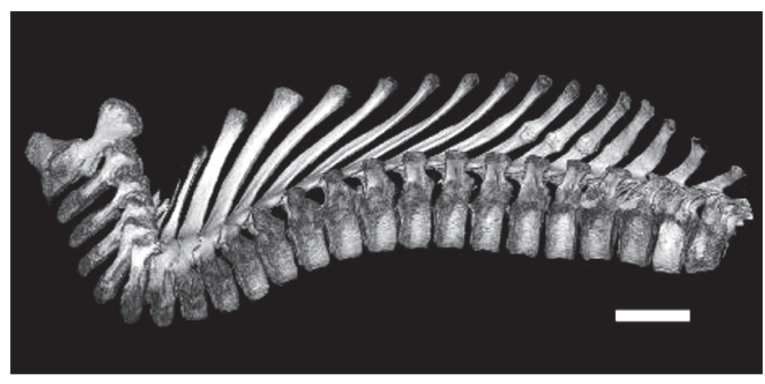

Fig. 2 Lateral view of 3D-image of the vertebrae of the bedridden Asian elephant (UMUT 12331). Scale bar indicates $10 \mathrm{~cm}$. 
the midpoints of the boundaries between the articular facets of the adjacent vertebrae and the ventral edges of the vertebral bodies from C2 to T5 (Fig. 4). The coordinates of these points were calculated 3 times, and the average value of the coordinates was used in the following analysis. To compare the 2 individuals presenting the different size and angle, we matched the digitized points that indicated the boundaries of the articular facets and the ventral edges of the vertebral bodies from $\mathrm{T} 1$ to $\mathrm{T} 5$ by translation and rotation using ordinary Procrustes analysis. We estimated the neck angle by calculating the regression line from 6 points indicating the boundaries of the posterior articular facets from C2 to C7.

\section{RESULTS}

\section{Description of the deformations of the vertebrae in the bedridden elephant}

CT scan images clarified the deformations of the articular processes of the vertebrae from C2 to T3 in the bedridden elephant. Articular processes usually possess flat facets; however, 10 facets of the cervical and cranial thoracic vertebrae in the bedridden elephant presented a rough surface (Table 1). Selected sagittal section images of the spine were illustrated for revealing the configuration of the articular processes (Fig. 3A). The posterior articular facets of C2 were formed as a ragged surface and a cavity was identified in the C2/C3 zygaphophyseal joint (Fig. 3E). The anterior articular facets of $\mathrm{C} 3$ also consisted of the irregular surfaces and a dorsal edge of the left facet intruded to the anterior adjacent facet (Fig. 3E). The right posterior articular process of $\mathrm{C} 3$ was dented and the right anterior articular process of $\mathrm{C} 4$ was elongated toward this interspace (Fig. 3B). Three protrusions were identified on the right posterior articular facet of C4 (Fig. 3C) and a cavity existed in the left posterior articular process of C4 (Fig. 3F). The left anterior articular facet of C5 was deformed such that the facet filled the cavity in the adjacent articular process (Fig. 3F). The left anterior articular facet of C6 was elongated anteroventrally and it partly intruded into the left posterior articular facet of C5 (Fig. 3F). The boundary between C5/C6 zygapophyseal joint was obscure and the articular facets between them were partly fused (Fig. 3F, G). Articular processes of C6 were completely coalesced with those of $\mathrm{C} 7$ and the boundary between these processes could not be recognized (Fig. 3B, F, G). Although the anterior articular facets of $\mathrm{T} 1$ were not elongated or protruded, the presence of
2 pits was confirmed on the anterior articular facets (Fig. 3C, F). The boundary between the T1/T2 zygapophyseal joint was obscure and partly fused (Fig. 3C). The articular facets in the T2/T3 zygapophyseal joint demonstrated uneven surfaces with small hollows distributed throughout (Fig. 3C). The posterior articular facets of $\mathrm{T} 3$ and the anterior articular facets of $\mathrm{T} 4$ possessed flat surfaces, and the boundary between these articular processes was clearly identified (Fig. 3C). In more caudal vertebrae than T4, the articular facets consisted of flat surfaces (Table 1). Each spinous process of C5 and C6 was interdigitated to that of their posterior adjacent vertebrae (Fig. 3D). An extremely thin spinous process was confirmed in $\mathrm{C} 7$ (Fig. 3D).

\section{Investigation of the abnormality of the neck angle}

A result of the image analyses through the ordinary Procrustes analysis demonstrated that the neck of the bedridden elephant was excessively bent dorsally (Fig. 4). Regression lines defined as the neck angle, calculated from the coordinates of the articular facets of the cervical vertebrae, were $y=-1.6 \times x-1.8$ in the bedridden elephant $(r=-0.95$, R-squared $=0.89, \mathrm{p}<0.01)$, and $\mathrm{y}=-0.51 \times \mathrm{x}-0.54$ in the hyperostotic elephant $(r=-0.99$, R-squared $=0.98, p<0.001)$. The angle between these regression lines was 30.4 degrees (Fig. 4).

\section{DISCUSSION}

The present study revealed that the articular facets possessed intricately rough surfaces in the cervical and cranial thoracic vertebrae in the bedridden elephant (Table1, Fig. 3). The articular processes in the cervical vertebrae were deformed and intruded to the adjacent processes (Fig. 3B, E, F), and a cavity was identified between the zygapophyseal joints except for C5/C6 and C6/C7 (Fig. 3B, C, E, F). The abnormal articular processes and facets were confirmed in 6 cervical vertebrae, excluding the atlas, and the first 3 thoracic vertebrae (Table 1). The neck is composed of the cervical vertebrae, muscles, and ligaments, and plays an important role in lifting and holding the head against the gravitational force. The nuchal ligament, the most essential structure for this role, consists of powerful elastic fibers saving metabolic energy by storing and returning elastic strain energy and assisting the dorsiflexion of the head and neck [4]. The large mammals, like Asian elephant or giraffe (Giraffa camelopardalis), possess a well-developed 




Fig. 3 Selected computerized tomographic (CT) images of the cervical and cranial thoracic vertebrae of the bedridden Asian elephant (UMUT 12331), showing the neck region in successive sagittal sections (B-G). (A) A dorsal view of the articulated cervical and thoracic vertebrae in the neck region for illustrating the levels of the sections that are exhibited in (B-G). (BC) Selected parasagittal sections revealing the configurations of the right articular processes and facets from C2 to T5. (D) A nearly mid-sagittal section to clarify the shape of the spinous processes. (E-G) Selected parasagittal sections displaying the shape of the left articular processes and facets from C2 to T5. Arrowheads in (C) and (G) indicate the obscure boundaries between the adjacent articular processes. Arrow in $(\mathrm{C})$ denotes the clear and flat boundary.

nuchal ligament on the neck region [5, 6], allowing the efficient support of the head [7]. However, the primary function of the nuchal ligament may not be fulfilled under the bedridden condition since the head is laid on the ground. A previous study argued that the abnormality of a ligament prevented normal development of body structure and physiology [8]. Under the bedridden condition, the nuchal ligament is contracted without the gravitational load of the head and neck, and induces the dorsiflexion of the neck. When the ligament is contracted beyond the mobility of the cervical vertebrae, the articular processes of the vertebrae would be squeezed by those of the adjacent vertebrae. The compressive force might cause the inflammation between the articular processes, and then prompt the abnormal ossifications of the articulations through the repairing process $[9,10]$. The insertion of the ligament is the skull and the spinous processes from $\mathrm{C} 2$ to $\mathrm{C} 6$, and the origin is those from T1 to T3 [5]; hence the attachment sites of the ligament correspond to the region where the deformities of the articular processes and facets were confirmed (Table 1). It suggests that the deformities of the articular processes and facets of the cervical and cranial thoracic vertebrae are affected by the unusual compressive force produced by the nuchal ligament under the bedridden condition. The surface of the articular facets may be formed flatly by not only a genetic factor, but also by the normal load of the force generated by the nuchal ligament and gravity.

The fusions of the articular processes were confirmed in C5/ C6, C6/C7, and T1/T2 zygapophyseal joints in the bedridden specimen (Table 1, Fig. 3G). The left articular process of $\mathrm{C} 7$ was completely coalesced with the left posterior articular process of C6, and the boundary between C6/C7 zygapophyseal joint could not be recognized. The previous studies noted the examples of the vertebral fusions of bedridden human patients; however they had been suffered from hyperostotic diseases like a progressive myositis ossificans or an endemic skeletal fluorosis [3, 11]. In these cases, the abnormal ossifications were confirmed not only in the neck region but also in the thoracic and lumber regions and the appendicular skeleton. The vertebral fusions in the bedridden elephant were concentrated in the cervicothoracic area, and these were not observed in the 






Fig. 4 Diagram showing the difference of the neck angle between the bedridden Asian elephant (UMUT 12331) and the hyperostotic Asian elephant (NSMT-M-31593). Circles indicate the characteristic points of the bedridden Asian elephant and the rhombuses indicate those of the hyperostotic Asian elephant. The digitized points indicate the midpoints of the boundaries between the articular facets and the ventral edges of the vertebral bodies from C2 to T5. They were superimposed between the bedridden and hyperostotic Asian elephants using the ordinary Procrustes analysis. Regression lines were calculated from the coordinates of 6 points indicating the boundaries of the articular facets of the cervical vertebrae. The solid line shows the neck angle of the bedridden Asian elephant $(y=-1.6 \times x-1.8, r=-0.95$, R-squared $=0.89$, $\mathrm{p}<0.01$ ), and the dashed line shows that of the hyperostotic elephant $(y=-0.51 \times x-0.54, r=-0.99$, R-squared $=0.98, p<0.001)$. Drawings painted to light grey show the contour of the 6 cervical vertebrae, except for the atlas, and first 5 thoracic vertebrae of the bedridden Asian elephant. Drawings painted to dark grey show the contour of those vertebrae of the hyperostotic elephant. The black scale bar indicates 10 $\mathrm{cm}$ in the case of the bedridden Asian elephant and the shaded scale bar indicates the same length in the case of the hyperostotic Asian elephant.

Table 1 Surface shape of the articular facet in each vertebra

\begin{tabular}{lccc}
\hline & Anterior articular facet & Posterior articular facet & Nuchal ligament ${ }^{1)}$ \\
\hline C2 & - & Rough & Attached \\
\hline C3 & Rough & Rough & Attached \\
\hline C4 & Rough & Rough & Attached \\
\hline C5 & Rough & Partly fused & Attached \\
\hline C6 & Partly fused & Completely fused & Attached \\
\hline C7 & Completely fused & Rough & Attached \\
\hline T1 & Rough & Partly fused & Attached \\
\hline T2 & Partly fused & Rough & Attached \\
\hline T3 & Rough & Flat & Attached \\
\hline T4 & Flat & Flat & Not attached \\
\hline T5 & Flat & Flat & Not attached \\
\hline T6 & Flat & Flat & Not attached \\
\hline T7 & Flat & Flat & Not attached \\
\hline T8 & Flat & Flat & Not attached \\
\hline 1) Mariappa, 1986 [5] & &
\end{tabular}

other part of the axial skeleton. It indicates a possibility that the vertebral fusions in the bedridden elephant are not related to the over-ossification diseases.
The contraction of the nuchal ligament beyond the neck mobility squeezes the vertebral joint under the bedridden condition, and the compressive force could destroy the 
articular processes when the force exceeds the strength of the bone. The ligament connects the skull with the spine beyond a ventral concavity of the axial skeleton in the cervicothoracic area [5]; hence the force generated by the contraction of the ligament is exerted intensively on the ventral concavity. Namely, the result demonstrates that the vertebral fusions were distributed concentrating on where the compressive force should be converged. It suggests that the vertebral fusions may be facilitated by the compressive force generated by the nuchal ligament beyond the neck mobility.

The image analysis revealed that the neck angle of the bedridden elephant was inclined more steeply by 30.4 degrees than that of the hyperostotic specimen (Fig. 4). The hyperostotic elephant had not been reared under the bedridden condition, and the over-ossifications in this specimen are regarded as a deformation caused by aging. The vertebral fusions by the spondyloarthropathy or ankylosing spondylitis are often observed in a proboscidean, and not related to the other abnormalities like a joint discomfort and lameness [12]. By using the neck angle of the hyperostotic elephant as an indicator of a normal neck, it is advocated that the neck of the bedridden elephant is dorsally bent at 30 degrees more than that of the animal with no history of the bedridden condition. Additionally, in the bedridden elephant, the CT scan images revealed the interdigitations of the spinous processes in $\mathrm{C} 5$ and C6, and the extremely thin spinous process in C7 (Fig. 3D). These deformations imply the reduction of the space where the caudal cervical vertebrae need for the elongation of the spinous processes. The dorsiflexion of the neck narrows this space, so these are the evidence showing that the neck of the bedridden specimen is extremely dorsally bent than that of the upright quadrupedal specimen. This study suggests that the contraction of the nuchal ligament under the bedridden condition causes the destruction of articular processes in cervicothoracic area, and then it induces the strong dorsiflexion of the neck in large mammals.

\section{ACKNOWLEDGEMENTS}

We are grateful to the staff of the Kobe Oji Zoo for donating the carcass of the bedridden Asian elephant, and to Mr. Masakazu Yokoshima (Ueno Zoological Gardens) for giving information about the hyperostotic elephant to us. We thank Dr. Shinichiro Kawada and Dr. Nozomi Kurihara (National Museum of Nature and Science, Tokyo) for allowing us to investigate the bone collection in the museum. Two anonymous reviewers and Dr. Yasuhisa Nakajima (University of Bonn) made valuable comments on earlier versions of this manuscript. This study was supported by Key Research Project "Studies on functional morphology and phylogeny" of National Museum of Nature and Science, Tokyo, JSPS Fellowship for Young Scientists to MG, Grants-in-Aid for Scientific Research (B) to HE (nos. 21370033 and 22405002), and Grants-in-Aid for Exploratory Research to HE (nos. 21658103 and 23658253) of the Ministry of Education, Culture, Sports, Science and Technology of Japan.

\section{REFERENCES}

1. Ross MD. 1984. The influence of gravity on structure and function of animals. Adv Space Res 4: 305-314.

2. Christiansen P. 2004. Body size in proboscideans, with notes on elephant metabolism. Zool J Linn Soc 140: 523-549.

3. Singh A, Dass R, Hayreh SS, Patiala J. 1962. Skeletal changes in endemic fluorosis. J Bone Joint Surg B 44: 806-815.

4. Alexander RM. 2002. Tendon elasticity and muscle function. Comp Biochem Physiol A 133: 1001-1011.

5. Mariappa D. 1986. Anatomy and histology of the Indian elephant. Indira Publishing House, Oak park.

6. Mitchell G, Skinner J. 2003. On the origin, evolution and phylogeny of giraffes Giraffa camelopardalis. Trans Royal Soc $S$ Afr 58: 51-73.

7. Takeshita K, Peterson ETK, Bylski-Austrow D, Crawford AH, Nakamura K. 2004. The nuchal ligament restrains cervical spine flexion. Spine 29: E388-393.

8. Frank CB. 2004. Ligament structure, physiology and function. J Musculoskel Neuron Interact 4: 199-201.

9. Khan MA. 2002. Ankylosing spondylitis: The facts. Oxford University Press, Oxford.

10. Atkinson K, Coutts F, Hassenkamp AM. 2005. Physiology in orthopaedics: A problem-solving approach. Churchill Livingstone, London.

11. Mather JH. 1931. Progressive myositis ossification. Br J Radiol 4: 207-210

12. Rothschild BM, Wang X, Shoshani J. 1994. Spondyloarthropathy in proboscideans. J Zoo Wildl Med 25: 360-366. 


\title{
原著 解剖学
}

\section{起立不全のアジアゾウにおける頸椎および頭位胸椎の変形}

\author{
郡司芽久 ${ }^{1,2) *}$, 高井 昭 ${ }^{3)}$, 遠藤秀紀 ${ }^{1)}$ \\ 1）東京大学総合研究博物館 ₹ 133-0033 東京都文京区本郷 7-3-1
}

2) 東京大学大学院農学生命科学研究科農学国際専攻 干 113-8657 東京都文京区弥生 1-1-1

3）神戸市立王子動物園 干 657-0838 兵庫県神戸市灘区王子町 3-1

[2014 年 3 月 21 日受領, 2014 年 7 月 24 日採択 $]$

要 約

起立不全のアジアゾウ（Elephas maximus）における頸部骨格を形態学的に検討し，起立不全時の長期間に渡る横臥姿勢が頸部 に与える影響について考察した。本研究で使用したアジアゾウは 1 歳時に起立不能になり, その後 3 年半, 横臥位で飼育された。 ゾウの死後, CT スキャンを用いて頸部骨格を観察したところ, 第二頸椎から第七頸椎, 第一胸椎から第三胸椎において, 椎間関 節面の異常形成が認められた。また，第五・第六頸椎の椎間関節および第一・第二胸椎の椎間関節では，関節突起の部分的な癒合 が確認された。第六頸椎の後関節突起は, 第七頸椎の前関節突起と完全に癒合していた。起立不全のアジアゾウの頸部骨格を他の アジアゾウと比較したところ, 起立不全の個体では, 頸部が 30.4 度背側に過剩屈曲していることが明らかになった。起立不全下 での横臥生活では, 頭頸部にかかる重力負荷が減少することにより, 項勒帯は収縮する。これに伴い, 頸部は過剩に背屈され, 椎 骨の関節突起間には圧縮力が発生すると考えられる。椎骨間に働く圧縮力は, 関節炎や骨破壊を引き起こし, その修復過程におい て異常な化骨形成を促進する可能性がある。実際に, 起立不全のアジアゾウでは, 関節突起の癒合は, 圧縮力が収束すると考え られる頸胸接合部で集中的に観察された。本研究は, 横臥姿勢時の項勒帯の収縮は, 大型哺乳類において, 頸部の過剰背屈および 椎骨関節突起の異常形成を引き起こす可能性があると結論付けた。

キーワード : アジアゾウ, 横臥位, 起立不全, 頸部, 項勒帯

一日本野生動物医学会誌 19(3)：79-86, 2014

\section{*責任著者：}

郡司芽久（E-mail: megu_850121a@yahoo.co.jp） 